\title{
Př́íprava učitele na výuku sexuální výchovy
}

\section{The teacher preparation for sex education teaching}

\author{
Kateřina Kadlč́́ková
}

\begin{abstract}
Abstrakt: Příspěvek se zaměřuje na učitele ZŠ a jejich př́ípravu na výuku sexuální výchovy. Popisuje sexuální výchovu jako neodmyslitelnou součást vyučování, kromě toho se zabývá metodami a prostředky, které učitel během své výuky využívá. Výsledky příspěvku se stanou součástí výzkumu $\mathrm{v}$ rámci Studentské grantové soutěže na Pedagogické fakultě UP v Olomouci zabývajícího se analýzou implementace sexuální výchovy do výuky na ZŠ. Výzkumnou metodou je zvoleno dotazníkové šetření zaměřené na učitele prvního stupně základních škol. Výzkumné šetření se bude provádět na základních školách ve Zlínském a Olomouckém kraji.
\end{abstract}

Klíčová slova: př́íprava učitele, sexuální výchova, metody, prostředky, dotazníkové šetření, učitel primární školy.

\begin{abstract}
The paper focuses on elementary school teachers and their preparation for Sex Education teaching. It describes Sex Education as an integral part of teaching, in addition it deals with the methods and means that teacher uses in his teaching. The results are also becoming part of the Research for Student Grant competition at the Pedagogical Faculty of Palacky University in Olomouc, analyzing the implementation of Sex Education into teaching at primary school. As a research method is selected survey focusing on teachers at first grade of elementary schools. The survey will be implemented at elementary schools in Zlín and Olomouc regions.
\end{abstract}

Keywords: teacher training, sex education, methods, survey, teacher, primary school.

\section{1 Úvod}

Když se vysloví sexuální výchova, většina si představí intimní část svého života, která je nepublikovatelná pro děti, zvláště pak pro žáky prvního stupně základní školy. Pravda je ovšem jiná. Sexuální výchova zahrnuje základní informace týkající se tělesného a hormonálního vývoje, pohlavních odlišností mezi dětmi, hygienických návyků, dále toho, jak vzniká a vyvíjí se plod v těle matky, nemocí, spojené se sexualitou, samozřejmě antikoncepčních prostředků a mnoho jiného. Je důležité vštěpovat dětem již od brzkého věku tyto informace, aby si udělaly vlastní představu a ujasnily si všechny své nejasnosti. A zde je důležitá funkce učitele. Měl by doplňovat ty informace, které rodiče svému dítěti poskytli a které mu nejsou jasné. Ve své př́pravě na výuku by měl myslet na to, jaké metody a prostředky použivat, aby své žáky zaujal a vštěpil jim co nejsrozumitelněji informace, které se sexuální výchovy týkají. 


\section{Podmínky vyučování sexuální výchovy}

Každý učitel, než se pustí do výuky předmětu, který se zabývá sexuální výchovou, by měl dbát podmínek, které s touto skutečností souvisí. Můžeme rozlišovat podmínky vnitřní a vnější. Mezi vnitřní podmínky zařazujeme vlastnosti dědičné, vrozené i získané, psychický stav nebo aktuální zdravotní stav. Z vnějších podmínek jsou známé ty historické, geografické, společenské apod. V dnešní době již rozlišujeme nový okruh podmínek, které jsou dle Täubnera (1996) rozlišené takto:

- Znalost úrovně vědomostí, postojů, dovedností a chování žáků v oblasti sexuální výchovy - je samozřejmostí, že pedagog musí ovládat úroveň vědomostí, postojů a dovedností, i chování žáků v oblasti sexuální výchovy.

- Znalost úrovně interpersonálních vztahů mezi žáky a schopnost vychovatele vytvářet pozitivní přátelské vztahy mezi žáky navzájem i mezi žáky a učitelem - tj. pedagogická dovednost učitele tvořící základní podmínku sexuální výchovy.

- Dobré materiální podmínky sexuální výchovy - sem se řadí místnost, která je vhodná pro výuku sexuální výchovy, kde vybavenost a zařízení musí navozovat správnou atmosféru. Můžeme zde zařadit i literaturu určenou k sexuální výchově, videofilmy, obrazové materiály atd.

- Dostatečný časový prostor pro sexuální výchovu - nejvhodnější jsou větší časové úseky, jež dovolují dávat jednotlivé jevy do souvislostí a umožňuje učiteli využívat větší škálu metod a prostředků.

- Pozitivní vztah celého učitelského sboru k sexuální výchově (Täubner, 1996).

\section{Organizační formy práce a metody uplatňované v hodinách sexuální výchovy}

\section{1 Organizační formy práce}

V současnosti jsou v pedagogické praxi nejvíce uplatňované ty formy výuky, které se rozlišují podle vztahu osobnosti studenta:

- Výuka hromadná, která se vyznačuje prací žáků ve velké skupině pod vedením učitele.

- Výuka skupinová, která se vyznačuje rozdělením žáků do menších skupin a každá skupina žáků je charakteristická dělbou práce, vzájemnou výpomocí a odpovědností všech členů skupiny za odvedenou prácí, opět pod vedením svého učitele.

- Výuka párová, je obdobou skupinové výuky, ale žáci pracují ve dvojicích, nejlépe spolužáci, kteří sedí vedle sebe v lavici.

- Výuka individuální, zde učitel pracuje s jednotlivcem nebo malou skupinou žáků.

\section{2 Aktivizační metody sexuální výchovy}

Jedná se o metody, ve kterých je typická velmi vysoká aktivita žáků a spolupráce žáka s učitelem i s probíraným tématem. Dle Janiše (1999) se rozlišují:

- Metody dialogické - tato metoda je postavena na slovní interakci mezi učitele a žákem nebo mezi žáky navzájem, kde je základem otázka - odpověd'.

- Metody problémové - problémová metoda patř́i mezi náročné na učitelovu přípravu a tvořivost, a proto jsou velmi málo využitelné. Podstatou problémových metod je žákovo rozhodování mezi alternativami, žák volí optimální řešení problému na 
základě svých vědomostí a dovedností, kde problém vyřeší sám nebo ve skupině svých vrstevníků.

- Metody inscenační - jedná se o nejnáročnější metodu problémového učení. Základem této metody je problém nebo konflikt, který děti samy představují. Na konci hry mohou žáci debatovat, hledat další možnosti řešení nebo uvádět vlastní zkušenosti.

- Metoda hrou - tato metoda je pro sexuální výchovu vhodná hlavně v tom, že žáky motivuje k sociálnímu učení, povzbuzuje jejich zvědavost, zvyšuje aktivitu pasivních členů skupiny, dovoluje nenásilné zavedení nových norem v chování dětí a učí děti citlivě vnímat a vyjadřovat své pocity.

\section{Dotazníkové šetření}

\section{1 Charakteristika výzkumného vzorku}

Dotazníkové šetření bylo zaměřeno na učitele 3., 4. a 5. tříd prvního stupně základní školy ve Zlínském a Olomouckém kraji. Z každého ročníku bylo vybráno 25 učitelů, kteří dotazníkové šetření podstoupili. Celkově se zúčastnilo 75 respondentů.

\section{2 Vyhodnoceni dotaznikového šetreni}

Tabulka 1

Zařadili jste sexuální výchovu do některého předmětu ve výuce na 1. stupni ZŠ?

\begin{tabular}{|c|c|c|c|c|c|c|c|c|}
\hline \multirow{2}{*}{ Odpověd' } & \multicolumn{2}{|c|}{ 3. trrída } & \multicolumn{2}{|c|}{ 4. třída } & \multicolumn{2}{|c|}{ 5. třída } & \multicolumn{2}{|c|}{ celkem } \\
\hline & $n$ & $\%$ & $n$ & $\%$ & $\mathrm{n}$ & $\%$ & $\mathrm{n}$ & $\%$ \\
\hline Ano & 19 & 76,0 & 23 & 92,0 & 25 & 100 & 67 & 89,3 \\
\hline $\mathrm{Ne}$ & 6 & 24,0 & 2 & 8,0 & 0 & 0,0 & 8 & 10,7 \\
\hline Celkem & 25 & 100 & 25 & 100 & 25 & 100 & 75 & 100 \\
\hline
\end{tabular}

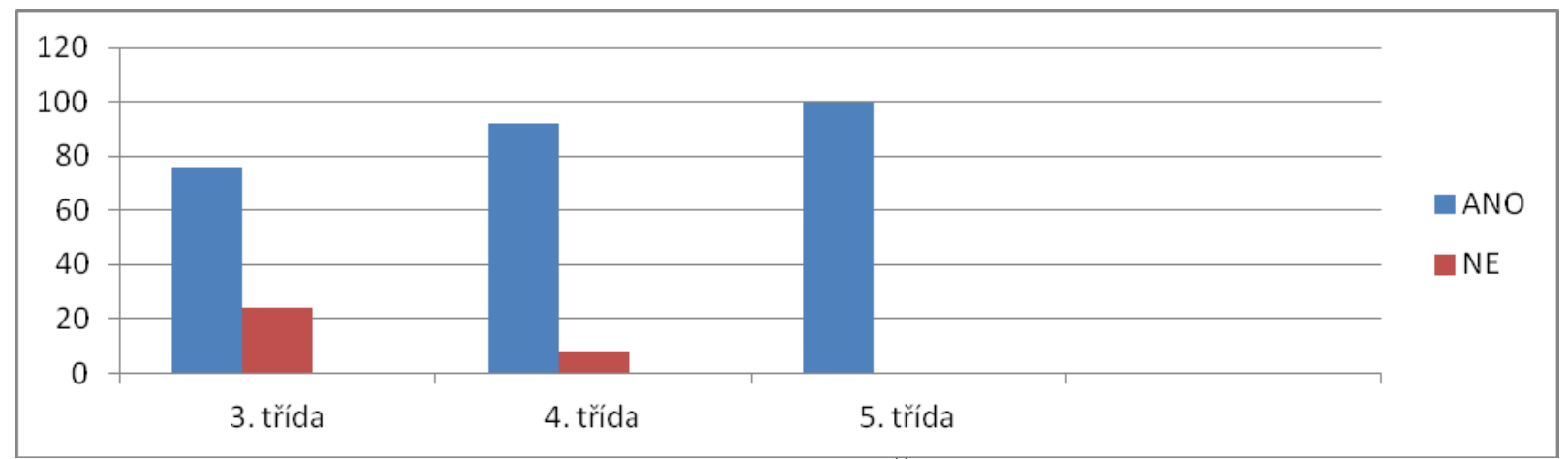

Obrázek 1. Zařazení sexuální výchovy do výuky na ZŠ

Komentář: Na otázku, zda učitelé zařazují sexuální výchovu do své výuky (viz tabulka a obrázek 1), odpovědělo 89,3 \% všech respondentů kladně a 10,7 \% záporně. Sexuální výchova se nejčastěji vyučuje v 5. tř̌́dě, všichni dotazovaní respondenti (100 \%) ji vyučují. Následuje 4. třída, z nichž $92 \%$ respondentů sexuální výchovu do svých osnov zařazují, 
pouze $8 \%$ z nich sexuální tématiku nevyučují. Nejméně dotazovaných respondentů vyučuje sexuální výchovu ve 3 . třídě, a to 76 \% ze všech dotazovaných respondentů.

Tabulka 2

Kolik hodin týdně vyučujete tento predmět?

\begin{tabular}{|l|l|l|l|l|l|l|l|l|}
\hline \multirow{2}{*}{ Odpověd' } & \multicolumn{3}{l}{3 . třída } & 4. tř́dala & 5. tř́dal & \multicolumn{2}{l|}{ celkem } \\
\cline { 2 - 10 } & $\mathrm{n}$ & $\%$ & $\mathrm{n}$ & $\%$ & $\mathrm{n}$ & $\%$ & $\mathrm{n}$ & $\%$ \\
\hline 1x týdně 1hodina & 19 & 76,0 & 23 & 92,0 & 25 & 100 & 67 & 67,0 \\
\hline 2x týdně 1 hodina & 0 & 0 & 0 & 0 & 0 & 0 & 0 & 0 \\
\hline $\begin{array}{l}\text { Nevyučuji sexuální } \\
\text { výchovu }\end{array}$ & 6 & 24,0 & 2 & 8,0 & 0 & 0 & 8 & 8,0 \\
\hline jiné & 0 & 0 & 0 & 0 & 0 & 0 & 0 & 0 \\
\hline
\end{tabular}

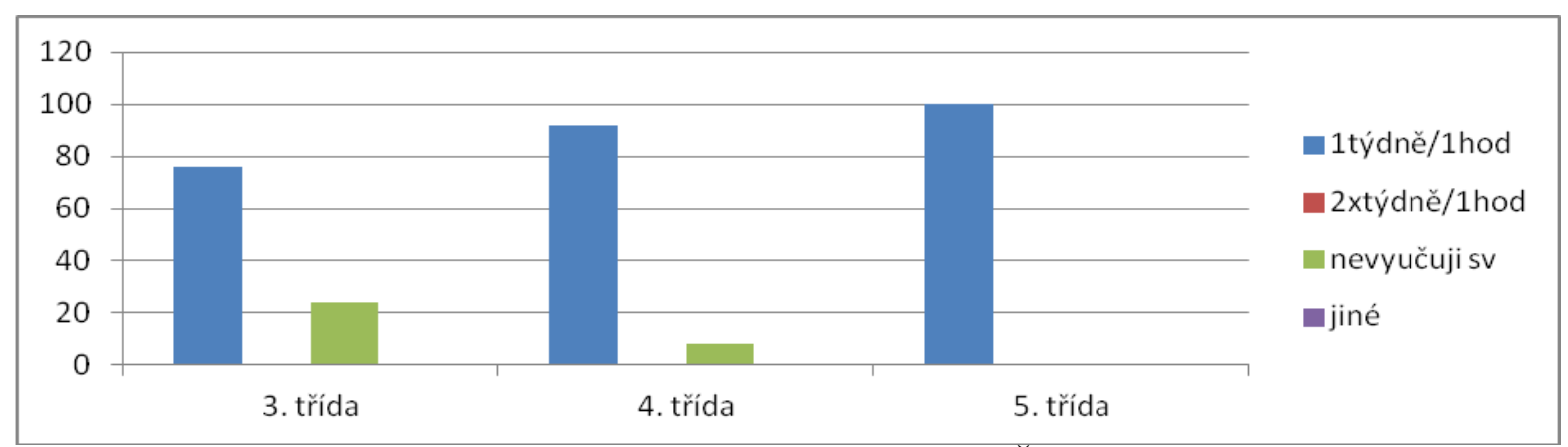

Obrázek 2. Počet vyučovacích hodin sexuální výchovy na ZŠ

Komentár̆: Ve 3. třídě $76 \%$ učitelů vyučuje sexuální výchovu alespoň 1xtýdně 1 hodinu, v tomto ročníku sexuální výchovu nevyučuje $24 \%$ dotazovaných učitelů. Ve 4 . tř́ídě se $92 \%$ dotazovaných respondentů vyjádřilo, že sexuální výchovu vyučují alespoň 1x/týdně, pouhých $8 \%$ tuto disciplínu nevyučuje. Všichni dotazovaní učitelé 5. ročníků $(100 \%)$ odpověděli, že sexuální výchovu vyučují 1x týdně jednu hodinu (viz tabulka a obrázek 2).

Tabulka 3

Jaké didaktické pomi̊cky v této výuce použiváte?

\begin{tabular}{|l|l|l|l|l|l|l|l|l|}
\hline \multirow{2}{*}{ Pomůcky } & \multicolumn{3}{l}{3 . tř́ída } & \multicolumn{2}{l|}{ 4. třída } & \multicolumn{2}{l|}{ 5. třída } & \multicolumn{2}{l|}{ celkem } \\
\cline { 2 - 10 } & $\mathrm{n}$ & $\%$ & $\mathrm{n}$ & $\%$ & $\mathrm{n}$ & $\%$ & $\mathrm{n}$ & $\%$ \\
\hline Nástěnné obrázky & 12 & 48,0 & 22 & 88,0 & 21 & 84,0 & 55 & 55,0 \\
\hline Televize/video & 6 & 24,0 & 19 & 76,0 & 14 & 56,0 & 39 & 39,0 \\
\hline Knihy/encyklopedie & 8 & 32,0 & 9 & 36,0 & 17 & 68,0 & 34 & 34,0 \\
\hline Pexeso & 15 & 60,0 & 4 & 16,0 & 0 & 0,0 & 19 & 19,0 \\
\hline Modely pohlaví & 11 & 44,0 & 23 & 92,0 & 24 & 96,0 & 58 & 58,0 \\
\hline Žádné pomůcky & 0 & 0,0 & 2 & 8,0 & 0 & 0,0 & 2 & 2,0 \\
\hline Jiné & 5 & 20,0 & 0 & 0,0 & 0 & 0,0 & 5 & 3,0 \\
\hline
\end{tabular}




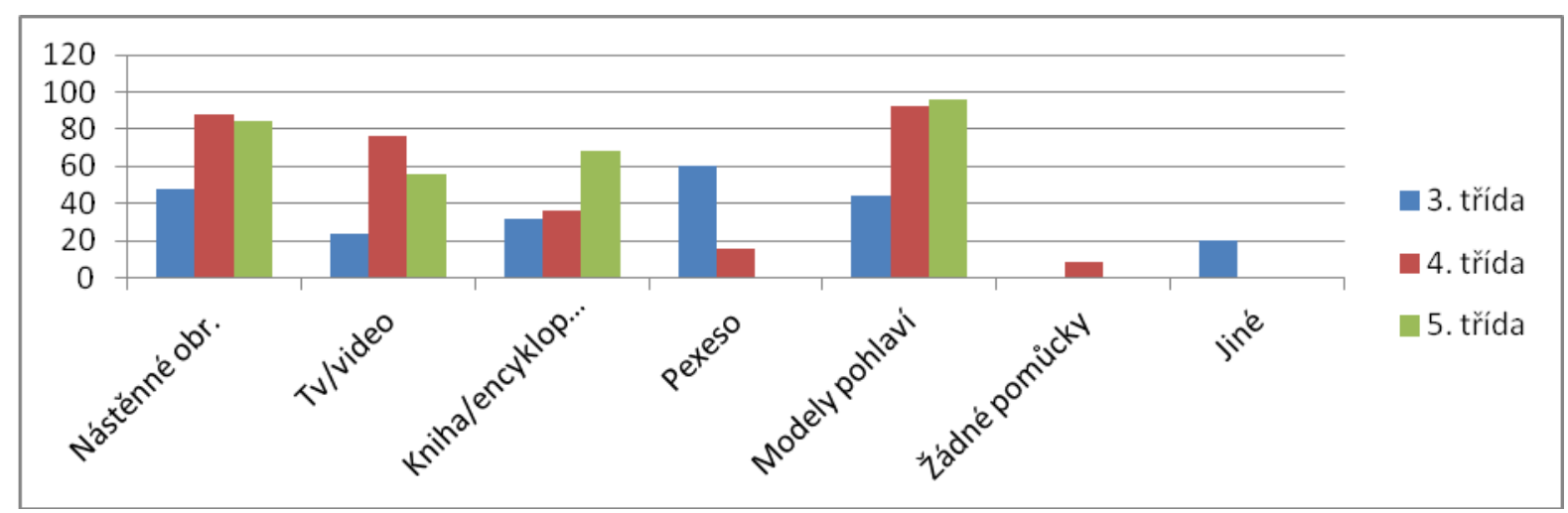

Obrázek 3. Didaktické pomůcky používané ve výuce sexuální výchovy

Komentář: Pomůcky, které se využívají při hodině sexuální výchovy (viz tabulka a obrázek $3)$, je ve 3. tř́dě nejčastěji uvedeno pexeso $(60,0 \%)$, nejméně využívána je televize, popř́ípadě video $(24,0 \%$ ) a $20,0 \%$ dotazovaných učitelů uvedlo, že využívají ve výuce modely panenek a dřevěné kostky. Učitelé 4 . trríd nejčastěji ve své výuce využívají modely pohlaví $(92,0 \%)$, následují nástěnné obrázky $(88,0 \%)$, nejméně využívanou pomůckou je pexeso $(16,0 \%)$ a $8,0 \%$ dotazovaných nevyužívá ve své výuce pomůcky žádné. V 5. tř́idě jsou nejčastěji využívanou pomůckou modely pohlaví $(96,0 \%)$, následují nástěnné obrázky (84,0 \%); dotazování respondenti 5. ročníku ve své výuce vůbec nevyužívají pexeso.

Tabulka 4

Jaké metody vyučování ve výuce použiváte?

\begin{tabular}{|l|l|l|l|l|l|l|l|l|}
\hline \multirow{2}{*}{ Metody } & \multicolumn{3}{l}{3. třída } & 4. trída & 5. trí́da & \multicolumn{2}{l|}{ celkem } \\
\cline { 2 - 11 } & $\mathrm{n}$ & $\%$ & $\mathrm{n}$ & $\%$ & $\mathrm{n}$ & $\%$ & $\mathrm{n}$ & $\%$ \\
\hline Dialogické & 19 & 76,0 & 23 & 92,0 & 24 & 96,0 & 66 & 66,0 \\
\hline Inscenační & 9 & 36,0 & 14 & 56,0 & 18 & 72,0 & 41 & 41,0 \\
\hline Problémové & 0 & 0 & 0 & 0 & 0 & 0 & 0 & 0 \\
\hline Hry & 17 & 68,0 & 20 & 80,0 & 22 & 88,0 & 59 & 59,0 \\
\hline Jiné & 0 & 0 & 0 & 0 & 0 & 0 & 0 & 0 \\
\hline
\end{tabular}

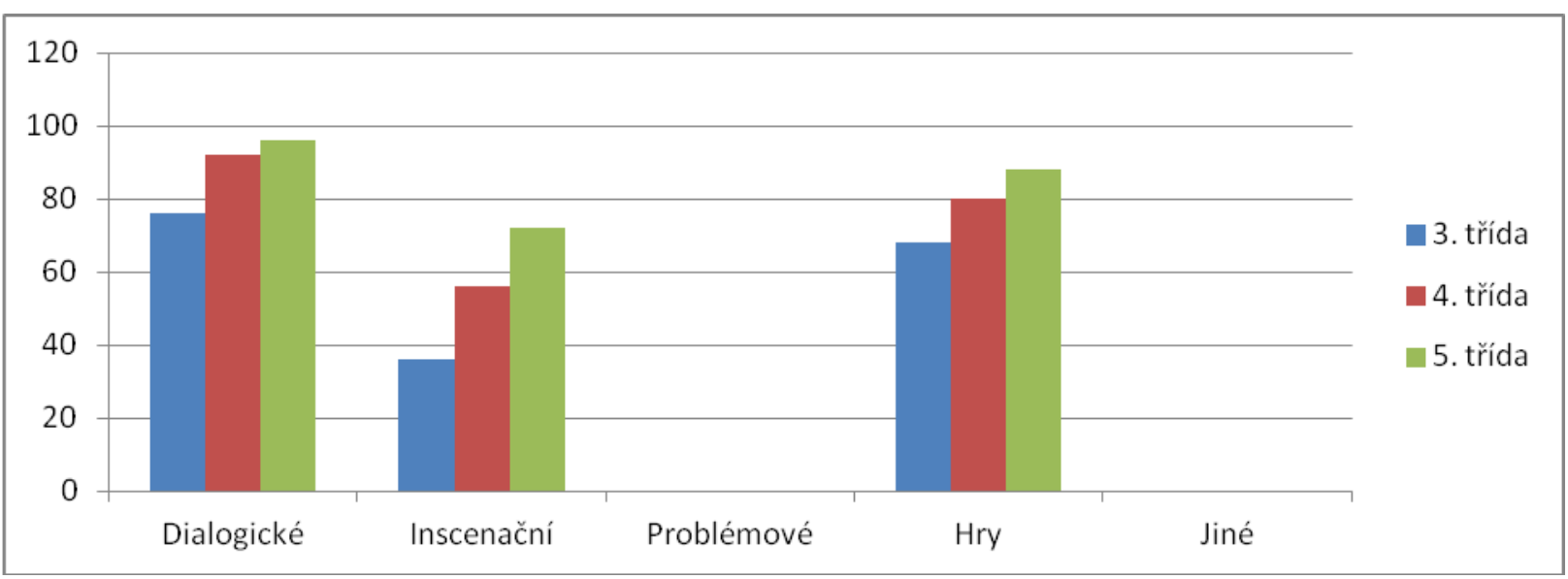

Obrázek 4. Metody ve výuce sexuální výchovy

Komentář: Na otázku, jaké metody využívají dotazovaní učitelé ve výuce sexuální výchovy (viz tabulka a obrázek 4), označilo $76,0 \%$ učitelů 3. tříd metodu dialogickou, následuje metoda hrou $(68,0 \%)$, nejméně se využívají metoda inscenační $(36,0 \%)$, dotazovaní učitelé 
3. tříd nevyužívají metodu problematickou. Ve 4. třídě, stejně jako učitelé 3. tříd, využívají nejvíce metodu dialogickou $(92,0 \%)$ a nejméně metodu inscenační $(56,0 \%)$. Stejně výsledky uvedli dotazovaní učitelé 5 . tříd, kteří rovněž za nejvíce využitelnou metodu považují metodu dialogickou $(96,0 \%)$ a nejméně používají metodu inscenační $(72,0 \%)$.

Tabulka 5

Z čeho čerpáte materiál pro výuku sexuální výchovy?

\begin{tabular}{|l|l|l|l|l|l|l|l|l|}
\hline \multirow{2}{*}{ Materiál } & 3. trrída & 4. třída & 5. tř́dala & \multicolumn{2}{l|}{ celkem } \\
\cline { 2 - 11 } & $\mathrm{n}$ & $\%$ & $\mathrm{n}$ & $\%$ & $\mathrm{n}$ & $\%$ & $\mathrm{n}$ & $\%$ \\
\hline Učebnice & 17 & 68,0 & 16 & 64,0 & 21 & 84,0 & 54 & 54,0 \\
\hline Internet & 12 & 48,0 & 22 & 88,0 & 11 & 44,0 & 45 & 45,0 \\
\hline Kolegové & 10 & 40,0 & 18 & 72,0 & 17 & 68,0 & 45 & 45,0 \\
\hline Vlastní nápady & 14 & 56,0 & 22 & 88,0 & 19 & 76,0 & 55 & 55,0 \\
\hline Jiné & 2 & 8,0 & 4 & 16,0 & 3 & 12,0 & 9 & 9,0 \\
\hline
\end{tabular}

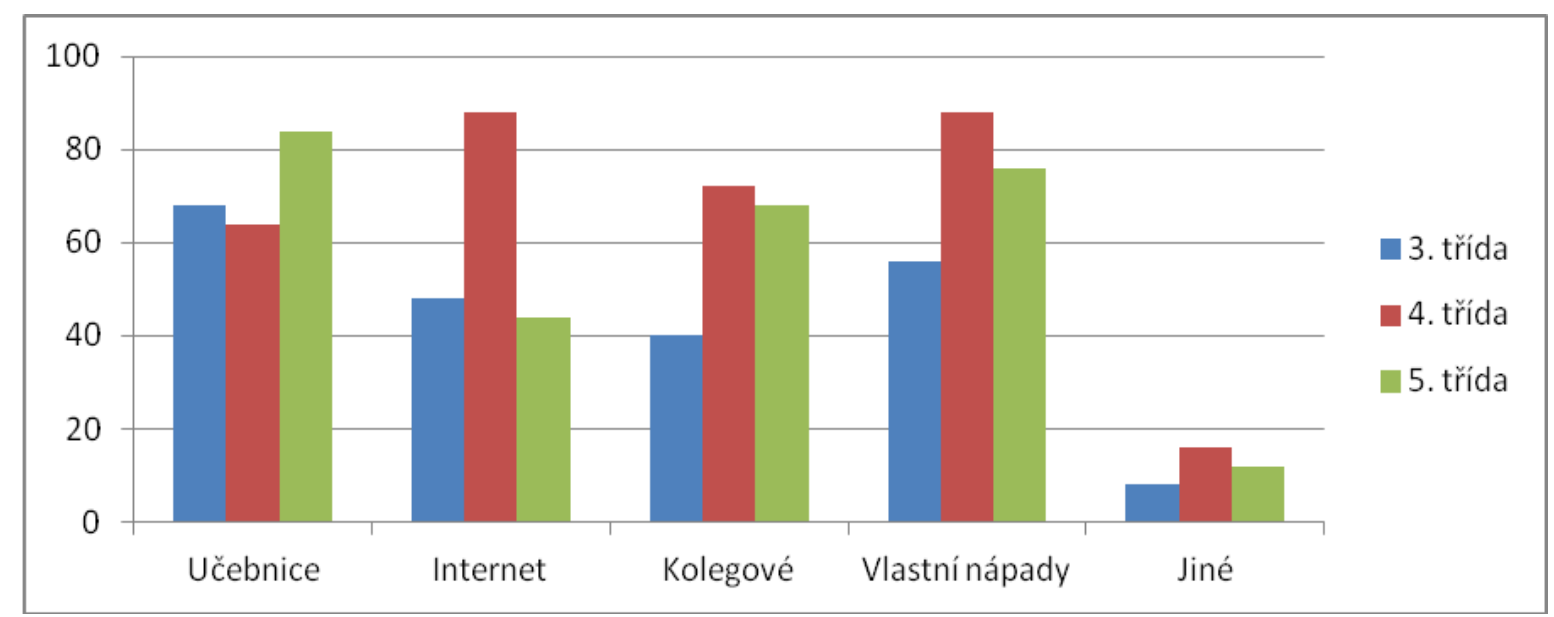

Obrázek 5. Materiál pro výuku sexuální výchovy

Komentář: Na 5. otázku (viz tabulka a obrázek 5) dotazovaní učitelé 3. trríd odpověděli, že nejvíce čerpají z učebnic pro př́slušný ročník $(68,0 \%)$, nejméně se radí se svými kolegy $(40,0 \%)$ a $8,0 \%$ uvedlo možnost jiné, kde využívají seminářu pro učitele, které se sexuální výchovy týkají. Ve 4 . trrídě odpovědělo $88,0 \%$ respondentů, že velmi často využívají internetu a vlastních nápadů do výuky sexuální výchovy, následuje konzultace s kolegy $(72,0 \%), 64,0 \%$ dotazovaných používá učebnice a rovněž jako dotazovaní učitelé 3. a 5. tříd se zúčastnili $16,0 \%$ dotazovaných respondentů 4 . třídy seminářů se sexuální tématikou. V 5 . třídě dotazovaným učitelům stačí učebnice $(84,0 \%)$, hned na to, následují vlastní nápady $(76,0 \%)$ a překvapivě nejméně využívají internet $(44,0 \%)$.

Tabulka 6

Seznamujete rodiče žáků s obsahem sexuální výchovy?

\begin{tabular}{|c|c|c|c|c|c|c|c|c|}
\hline \multirow{2}{*}{ Obsah SV } & \multicolumn{2}{|c|}{ 3. třída } & \multicolumn{2}{|c|}{ 4. třída } & \multicolumn{2}{|c|}{ 5. tř́ída } & \multicolumn{2}{|c|}{ celkem } \\
\hline & $\mathrm{n}$ & $\%$ & $\mathrm{n}$ & $\%$ & $\mathrm{n}$ & $\%$ & $\mathrm{n}$ & $\%$ \\
\hline Ano & 18 & 72,0 & 20 & 80,0 & 21 & 84,0 & 59 & 59,0 \\
\hline $\mathrm{Ne}$ & 0 & 0,0 & 3 & 12,0 & 1 & 4,0 & 4 & 4,0 \\
\hline Rodiče nemají zájem & 1 & 4,0 & 0 & 0,0 & 3 & 12,0 & 4 & 4,0 \\
\hline
\end{tabular}




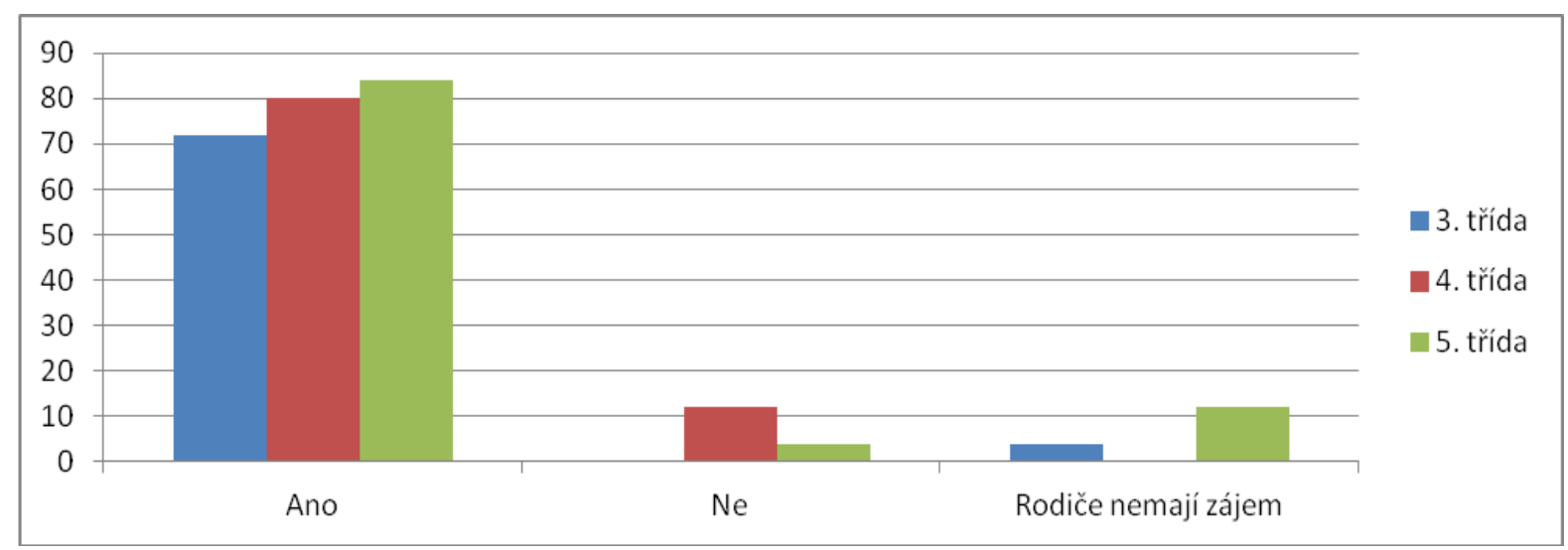

Obrázek 6. Seznamování rodičů s obsahem sexuální výchovy

Komentář: Na otázku zda seznamují učitelé rodiče žáků s obsahem sexuální výchovy (viz tabulka a obrázek 6), odpovědělo $72,0 \%$ dotazovaných učitelů 3. tříd, $80,0 \%$ učitelů 4 . tříd a $84 \%$ učitelů 5. tříd kladně, $12,0 \%$ dotazovaných učitelů 4 . třída a $4,0 \%$ učitelů 5 . tř́íd odpovědělo záporně. $4,0 \%$ učitelů 3 . třídy, kteří odpovídali na tento dotazník, uvedli, že rodiče o tuto oblast nejeví zájem, rovněž $12,0 \%$ učitelů 5. třídy se na této odpovědi shoduje s učiteli 3. tř́ídy.

\section{Závěr}

Sexuální výchova je v dnešní době velmi rozšiřrené a diskutované téma, nejen ve školách, ale $\mathrm{i}$ v médiích. Je nejen na učitelích, ale i na rodičích, aby své žáky a potomky do této oblasti zasvětili. Pravdou ovšem zůstává, že většina rodičů se tomuto tématu vyhýbá a raději přenechají, aby žáky o této skutečnosti informovali učitelé. Na učitele tak padá břemeno, kdy musí žáky naučit nejzákladnějším věcem z oblasti sexuální výchovy a zde je proto důležitá jeho př́prava na samotnou výuku.

Z dotazníkového šetření bylo zjištěno, že výuka se sexuální tematikou se nejčastěji vyučuje $\mathrm{v}$ 5. trrídě. Rovněž se zjistilo, že učitelé dávají přednost ve výběru pomůcek osvědčeným věcem, jako jsou nástěnné obrázky či modely pohlaví, před ostatními pomůckami. Metoda, které je nejvíce využívána, je metoda dialogická. Dotazovaní respondenti uvedli, že nejvíce nápadů do výuky čerpají z vlastních zkušeností. Ve většině prŕípadů jsou rodiče seznámení s obsahem sexuální výchovy, jen malá část dotazovaných uvedla, že rodiče se o tuto oblast nezajímají.

\section{Literatura}

Donát, J., \& Donátová, N. (1996). Důvěrně a otevřeně o sexualitě. Praha: Fortuna Janiš, K., \& Täubner, V. (1999). Didaktika sexuální výchovy. Hradec Králové: Gaudeamus.

Täubner, V. (1996). Metodika sexuální výchovy pro učitele, vychovatele, rodiče a studenty učitelství. Praha: Fortuna.

\section{Kontakt}

Mgr. Kateřina Kadlčíková

UP v Olomouci

Pedagogická fakulta, Katedra primární pedagogiky

Žižkovo nám. 5, 77140 Olomouc

e-mail: KadlcikovaKatka@ seznam.cz 


\section{Bibliografické údaje}

Kadlčíková, K. (2011). Příprava učitele na výuku sexuální výchovy. In T. Janík, P. Knecht, \& S. Šebestová (Eds.), Smišený design v pedagogickém výzkumu: Sborník př́spěvků z 19. výroční konference České asociace pedagogického výzkumu (s. 421-428). Brno: Masarykova univerzita.

Dostupné z: http://www.ped.muni.cz/capv2011/sbornikprispevku/kadlcikova.pdf doi: 10.5817/PdF.P210-CAPV-2012-20 